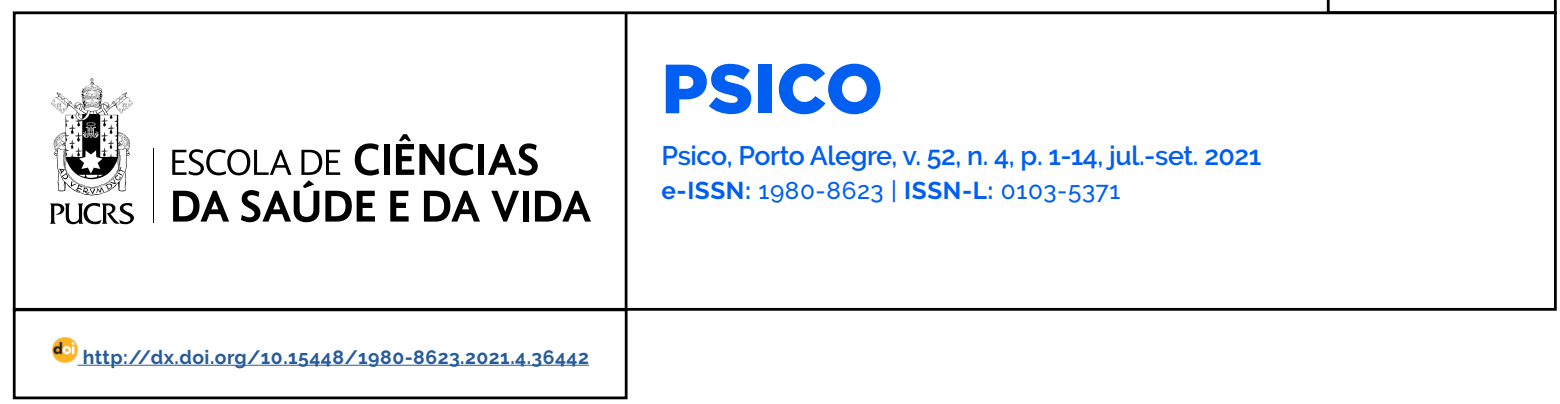

SEÇÃO: ARTIGO

\title{
Development of the Dimensional Clinical Personality Inventory Antisocial Personality Disorder Scale based on the HiTOP
}

\author{
Desenvolvimento da Escala Transtorno da Personalidade Antissocial do Inventário \\ Dimensional Clínico da Personalidade de acordo com o HiTOP \\ Desarrollo del Inventario Dimensional de Personalidad Clínica Escala de Trastornos de \\ Personalidad Antisocial basada en HiTOP
}

\section{Lucas de Francisco \\ Carvalho ${ }^{1}$ \\ orcid.org/0000-0002-3274-9724 \\ lucas@labape.com.br}

\section{Ana Deyvis Santos \\ Araújo Jesuino ${ }^{1}$}

orcid.org/0000-0002-7031-7682

anadeyvis@gmail.com

\section{Samanta Romanin}

Zuchetto $^{1}$

orcid.org/0000-0002-4709-5276 samanthazuchetto@hotmail.com

\section{Ana Carolina Zuanazzi ${ }^{1}$ \\ orcid.org/0000-0003-1649-2372 anacarolina.zf@gmail.com}

Recebido em: 15 nov. 2019. Aprovado em: 28 abr. 2020. Publicado em: 19 jan. 2022.

\section{(c) (i)}

Artigo está licenciado sob forma de uma licença Creative Commons Atribuição 4.0 Internacional.
Abstract: We aimed to develop a version of the Dimensional Clinical Personality Inventory 2 (IDCP-2) according to the Hierarchical Taxonomy of Psychopathology (HiTOP) for the assessment of antisocial personality disorder traits (i.e., IDCP Antisocial Personality Disorder Scale; IDCP-ASPD), as well as verify its psychometric properties. We developed new factors to cover ASPD traits, and collect data with 206 adults from the community $\left(M_{\text {age }}=31.3 ; 77.8 \%\right.$ women). Participants completed the IDCP-ASPD, factors from IDCP-2, and Personality Inventory for DSM-5 (PID-5). Exploratory structural equation modeling (E-SEM) suggested a 3 -factors solution, grouping the 14 factors composing the IDCP-ASPD. Reliability indicators were good. Correlations between IDCP-ASPD and external measures corroborated expectations. The bootstrap two-sample t-test comparing non-clinical and psychiatric groups suggested good discrimination capacity of the IDCP-ASPD. Favorable evidence was found for the usability of the developed scale for ASPD traits measurement, although future studies must replicate the findings in samples composed by ASPD patients.

Keywords: personality disorders, differential diagnosis, psychopathy, psychological assessment

Resumo: Nosso objetivo foi desenvolver uma versão do Inventário Dimensional Clínico da Personalidade 2 (IDCP-2) com base no Hierarchical Taxonomy of Psychopathology (HiTOP) para avaliar traços do transtorno da personalidade antisocial (i.e., IDCP escala Antissocial; IDCP-ASPD), e verificar suas propriedades psicométricas. Novos fatores foram desenvolvidos para cobrir traços do transtorno, e dados foram coletados com 206 adultos $\left(M_{\text {idade }}=31,3 ; 77,8 \%\right.$ mulheres), que responderam: IDCP-ASPD, fatores do IDCP-2 e do Personality Inventory for DSM-5 (PID-5). A exploratory structural equating modeling (E-SEM) indicou três fatores, agrupando os 14 fatores que compõem o IDCP-ASPD. A precisão foi adequada. As correlações do IDCP-ASPD com as medidas externas corroboraram as expectativas. O bootstrap two-sample t-test sugeriu boa discriminação para os grupos não-clínico e psiquiátrico. Evidências favoráveis foram encontradas para uso do IDCP-ASPD, embora os achados precisem ser replicados em pacientes com transtorno da personalidade antissocial.

Palavras-chave: transtornos da personalidade, diagnóstico diferencial, psicopatia, avaliação psicológica

Resumen: Nuestro objectivo fue desarollar una version del Inventário Dimensional Clínico da Personalidade 2 (IDCP-2) que se basó en Hierarchical Taxonomy of Psychopathology (HiTOP) para evaluar rasgos del transtorno de personalidad antisocial (i.e., IDCP escala Antissocial; IDCP-ASPD), y verificar sus propriedades psicometricas. Nuevos factores fueran desarollados para nuevos rasgos del transtorno, y dados fueran coletados con 206 adultos $\left(M_{\text {idad }}=31,3\right.$; 
$77,8 \%$ mujeres), responderan: IDCP-ASPD, factores del IDCP-2 y del Personality Inventory for DSM-5 (PID-5). El exploratory structural equating modeling (E-SEM) indicó tres factores, agrupando los 14 factores que componem el IDCP-ASPD. La precisión fue adecuada. Las corelaciones del IDCP-ASPD com las medidas externas corroboraron las expectativas. O bootstrap two-sample t-test apuntó buena discriminación para los grupos no clínico y psiquiatrico. Encontramos evidencias favorables para el uso de IDCP-ASPD, aunque los hallazgos deben ser replicados en pacientes con trastorno de personalidad antisocial.

Palabras clave: transtornos de la personalidad, diagnóstico diferencial, psicopatia, evaluación psicológica

Antisocial personality disorder (ASPD) is a psychiatric condition characterized by the violation of the rights of others, and the presence of impulsivity, irritability, absence of remorse, aggression, and irresponsibility traits (Coid, 2003); for an etiological review, see (Glenn, Johnson, \& Raine, 2013; Rautiainen et al., 2016). ASPD diagnosis is focused on adults and remains stable throughout life (Brito \& Hodgins, 2009).

The estimated occurrence for ASPD is between $0.2 \%$ and 3.3\% for community samples (APA, 2013). When weighted by sex, findings suggest men presenting three more times this disorder than women (Derefinko \& Widiger, 2016; Glenn et al., 2013). In forensic samples, these values increase to approximately 50\% in men (Coid \& Ullrich, 2010; Fazel \& Danesh, 2002), and 31.8\% in women (Coid \& Ullrich, 2010). In a review of epidemiological data (Robins, Tipp, \& Pryzbeck, 1991), 47\% of people filled in criteria for ASPD according to the DSM-III. These individuals presented successive prison records, and difficulties as workplace problems, violence, traffic offenses, and severe marital problems. Conduct deviations related to lack of impulse control or hostile behaviors may also be present in individuals diagnosed with ASPD (Santana et al., 2018; Wallace, Malterer, \& Newman, 2009; Widiger, 2011).

The current diagnostic system to ASPD is categorical (APA, 2013), although criticisms to using this model, in this case, were previously presented (Glenn et al., 2013; Lynam \& Vachon, 2012; Whitbourne \& Halgin, 2015; Yakeley \& Williams, 2014). Studies suggest that ASPD (Marcus, Lilienfeld, Edens, \& Poythress, 2006; Walters, 2008) and psychopathologies in general (Wright et al.,
2013), should be understood under a dimensional nature.

According to recent criticisms of the current diagnostic system, Kotov et al. (2017) proposed the Hierarchical Taxonomy of Psychopathology (HiTOP). The HiTOP is an evidence-based proposal for hierarchical classification of symptoms and traits that make up psychiatric disorders. It is a dimensional phenotypic model that provides informative and valuable descriptions in research and clinical practice. It is presented in a hierarchical structure, consisting of five levels, starting from a broader perspective of disorders (i.e., super spectrum and spectra) to more specific and detailed levels (i.e., sub-factors, disorders, traits, and symptoms) (Hengartner \& Lehmann, 2017). The broader levels investigate heterogeneous aspects that allow the grouping of psychiatric disorders (Kotov et al., 2017).

As a dimensional model, the HiTOP intends to solve the typical limitations from a categorical perspective, and is based on empirical evidence, combining symptoms and traits to emerge psychopathology components as spectra (e.g., internalizing and externalizing) (Conway et al., 2018). The authors identified six spectra: Somatoform, Internalizing, Thought Disorder, Disinhibited Externalizing, Antagonistic Externalizing, and Detachment, although empirical evidence are just initial (Forbes et al., 2017). ASPD is related to the disinhibited externalizing e antagonistic externalizing spectra, including the antisocial behavior subfactor, but not the substance abuse subfactor (Gomez \& Corr, 2014; Wright \& Simms, 2015), as this subfactor is related to the risk-taking trait, but is not considerate as a core trait of the ASPD (APA, 2013; Kotov et al., 2017).

According to the HiTOP model, the antisocial behavior subfactors are composed of the following traits: problematic impulsivity, irresponsibility, theft, distractibility, risk-taking, (low) rigid perfectionism, (low) ruminative deliberation, and (low) workaholism. Moreover, the spectra antagonistic externalizing is also composed of the following traits: impatient urgency, (low) planful control, (low) dependability, alienation, boredom 
proneness, blame externalization, (low) honesty, rebelliousness, (low) empathy, excitement seeking (Kotov et al., 2017).

According to Kotov et al. (2017), there is no measure encompassing all traits included in the HiTOP. They presented several measures covering some of the traits (Conway et al., 2018; Kotov et al., 2017). For instance, ASPD measures were the Personality Inventory for DSM-5 (PID-5), the Personality Assessment Inventory (PAI), and the Five-Factor Model Personality Disorder (FFM-PD) (Crego \& Widiger, 2016; Hopwood, Thomas, Markon, Wright, \& Krueger, 2012), and the Minnesota Multiphasic Personality Inventory-2 Restructured Form (MMPl-2-RF; Anderson et al., 2015).

Although some of these measures are world-renowned, they are not available for several countries. For instance, in Brazil, where this study took place, the PAI and the MMPI-2-RF are not available. Because of that, assessment tools have been nationally developed, as the Dimensional Clinical Personality Inventory (IDCP), a self-report measure for pathological traits assessment in its second edition (IDCP-2; Carvalho \& Primi, 2018). The IDCP-2 was developed under the dimensional assumption, and each of its dimensions has been recurrently refined according to current proposals and perspectives (e.g., Carvalho, Sette, \& Ferrari, 2016). Evidence of the association between the HiTOP spectra and IDCP-2 dimensions were previously found (Pianowski, Carvalho, \& Miguel, 2019), suggesting that IDCP-2 evaluates higher (i.e., spectra) and low order (i.e., traits) dimensions of the HiTOP, as recommended in the literature (Conway et al., 2018).

Although none of the dimensions of IDCP-2 sufficiently represent all the ASPD traits, there is evidence that the Inconsequence dimension (called Impulsiveness in IDCP first version) is closely related to the typical traits from the ASPD (Carvalho, 2018; Carvalho \& Primi, 2016). Traits covered by the Inconsequence dimension are impulsivity, risk-taking, and deceitfulness subfactors, considered as core traits of the ASPD (Glenn et al., 2013; Yakeley \& Williams, 2014), in addition to other traits (e.g., dominance and callousness) from the Grandiosity dimensions, for instance (Carvalho, Sette, et al., 2016).

While IDCP-2 dimensions are composed of factors measuring traits considered relevant in the assessment of ASPD, some features listed in the HiTOP spectra related to ASPD are not represented in the evaluative content that composes IDCP-2. Based on that gap, this study aimed to update IDCP-2 according to HiTOP and develop a version of the IDCP-2 focused on the ASPD traits based on HiTOP (i.e., IDCP Antisocial Personality Disorder Scale; IDCP-ASPD), as well as verify its psychometric properties.

\section{Methods}

This study was developed in two main steps. In the first one, we reviewed the IDCP-2 based on HiTOP and focused on ASPD traits. From this review, we created a version of the instrument to evaluate the typical traits of ASPD according to HiTOP, IDCP-ASPD. In Step 2, we aimed to investigate the psychometric properties of IDCP-ASPD, specifically internal consistency reliability coefficients and internal structure and external criteria validity evidence.

\section{Step 1}

Initially, it was carried out a survey and selection of personality traits characteristic of the ASPD according to the HiTOP model. We selected the spectra related to ASPD (Kotov et al., 2017) and, consequently, the corresponding traits. Traits definitions were according to the PID-5 (Krueger, Derringer, Markon, Watson, \& Skodol, 2012), as one of the measures indicated by Kotov et al. (2017). To be consistent with this, we also based our survey on traits definitions presented by Krueger et al. (2012).

From this, the factors of the IDCP-2 that contained a definition similar to the HITOP traits were analyzed and selected. The IDCP-2 factors did not contemplate some traits of the HiTOP model, and therefore, we developed new items. The authors of this study independently created the items. For this purpose, we followed the recommendations on item development (e.g., AERA, APA, \& NCME, 
2014). We organized the traits not represented by any IDCP-2 factors in a digital spreadsheet. Each author should create at least one item per trait. As a final step, each author voted for the group of items to be administered in the data collection, according to its clarity, content, and relevance. In other words, we selected from a pool of items only those that match the criterion of suitability and consistency with the disorder/specific trait definition.

\section{Step 2 \\ Participants}

Participants were 206 individuals, 18-72 age range ( $M=31,3 ; S D=10,17), 161$ women (77.8\%). Of the participants, the majority had completed graduate studies $(34.3 \%, N=71)$, and were single $(64.7 \%, \mathrm{~N}=134)$. Also, information was collected about the clinical status of participants, $23.2 \%$ $(\mathrm{N}=48)$ declared had done or are in psychiatric treatment, $11.1 \%$ ( $\mathrm{N}=23$ ) use medication, and $66.2 \%$ $(\mathrm{N}=137)$ had done or are psychological treatment. Besides that, 4.3\% ( $\mathrm{N}=9)$ declared a suicide attempt in the past, 38.6\% ( $\mathrm{N}=80)$ declared suicide ideation in the past, and $7.2 \%(\mathrm{~N}=15)$ declared suicide ideation in the present days.

\section{Measures}

IDCP Antisocial Personality Disorder Scale; ID$C P-A S P D$. This self-report instrument aims to evaluate the pathological aspects of personality through 206 items distributed in 12 dimensions (Dependence, Aggressiveness, Humor Instability, Eccentricity, Attention Seeking, Distrust, Grandiosity, Isolation, Criticism Avoidance, Self-sacrifice, Conscientiousness, and Inconsequence), subdivided into 47 factors. Specifically, the scale elaborated in the present study aims to evaluate the ASPD traits according to HiTOP, and the following factors were applied: Indifference ( $\alpha=.71$ ) and Dominance $(\alpha=.81)$, both from Grandiosity Dimension; Impulsivity ( $\alpha=.76$ ), Risk-Taking ( $\alpha=.90$ ) and Callousness ( $\alpha=.80$ ) from Inconsequence Di- mension and Seduction and manipulation ( $\alpha=.78$ ) from Attention Seeking Dimension. Besides, 35 new items were developed to compose factors evaluating traits not measured by IDCP-2.

The items are answered on a four-point Likert scale, ranging from 1 "has nothing to do with me" to 4 "has a lot to do with me". The psychometric properties of the factors were showed in previous studies (Carvalho \& Martins, 2017; Carvalho, Pianowski, \& Miguel, 2015; Carvalho, Pianowski, Silveira, Bacciotti, \& Vieira, 2016; Carvalho \& Primi, 2018; Carvalho, Sette, et al., 2016).

Personality Inventory for DSM-5 - PID-5 (Krueger et al., 2011). It's a 220-item self-report instrument for assessing pathological personality characteristics, distributed in 25 facets that are grouped in five higher-order domains (Negative affectivity, Detachment, Antagonism, Disinhibition, and Psychoticism). In the present study, the following facets were used: Impulsivity, Irresponsibility, Risk-taking, Callousness, Deceitfulness, Manipulativeness and, Grandiosity.

The items are answered on a four-point Likert scale, ranging from o "has nothing to do with me, very false" to 3 "has a lot to do with me, very true". No national studies were found to verify the psychometric properties of the Brazilian version of the instrument, but Krueger et al. (2011) present data indicating the adequacy of the original version of the test. In our sample, Cronbach's alphas were from .61 (Irresponsibility) to .90 (Attention Seeking).

\section{Procedures}

According to Resolution CNS 510/2016 of National Health Council (Conselho Nacional de Saúde, 2016), ethics research principles with human beings were considered to execute this research. The data collection lasted a month and was conducted online. We used Google Forms, including the informed consent form, the demographics questions, and the scales. We invited people to participate in the study through Facebook ads. The response time mean was 30 minutes. 


\section{Statistical Analysis}

In step 1, we selected the relevant traits for the ASPD according to HiTOP, which are presented in Table 1. From this selection, new items were developed, and new factors established, achieving the version to the administration of the IDCP-ASPD. In step 2, psychometric properties were verified through exploratory factor analysis (EFA), using parallel analysis to indicate the number of factors. Internal consistency and intracorrelations were calculated as indicators of reliability. Correlations were performed between the IDCP-ASPD factors and the respective external measures according to Table 1. We also proceeded to bootstrap $(k=$ 10.000; bias-corrected 95\% confidence intervals - Cl) two-sample t-test, creating two groups from total sample: healthy group $(n=66)$, composed by people that related never having done psychotherapy and psychiatric treatment, as well reported no suicidal attempt and suicidal thoughts, and pathological group ( $n=29$ ), composed by people that reports having a psychiatric diagnosis and participate on psychiatric treatment. We use $\mathrm{R}$ software version 3.4.0 for parallel analysis calculation, MPlus software version 7 for EFA, and SPSS software version 21 for reliability, correlations, and test $t$ with bootstrap. The $p$-value level was $\leq .05$.

\section{Results}

Step 1 - IDCP-2 revision procedures according to pathological traits from spectra of the HiTOP model

In Table 1 the spectra from HiTOP related to the ASPD are presented, as well the respective traits, and the typical traits of the ASPD. Traits selection was made independently by the researchers of the study. The consensus was reached when discordances emerged. In other words, as the HiTOP literature presents which traits should compose each group of disorders, we confirmed the inclusion of each trait in our study in an independent way by each author. The table also contains the IDCP-2 factors, developed measures, and external correspondent measures representing the ASPD traits from HiTOP. 
Table 1 - Relevant traits, IDCP-ATS factors, and external measures

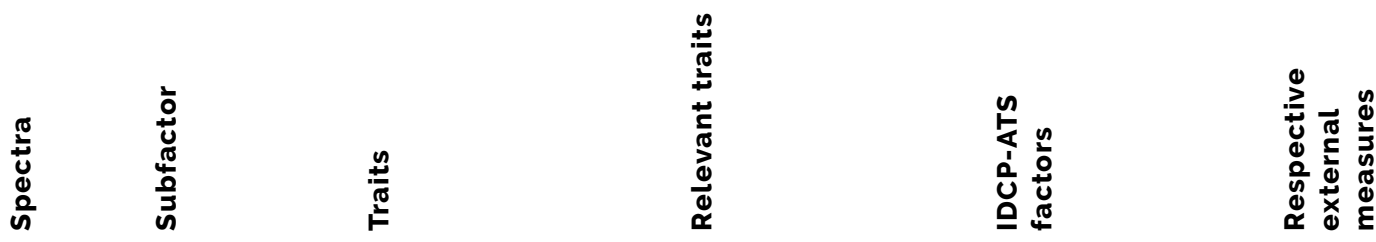

\begin{tabular}{|c|c|c|}
\hline & \multicolumn{2}{|l|}{ Risk-taking } \\
\hline & Problematic impul- & Risk-taking \\
\hline & sivity & Problematic \\
\hline & Irresponsibility & impulsivity \\
\hline & Theft & Irresponsibilit) \\
\hline & (low)workaholism & Theft \\
\hline & (low) Ruminative & -- \\
\hline & deliberation & -- \\
\hline & (low) Rigid perfectio- & -- \\
\hline & nism & -- \\
\hline & Distractibility & \\
\hline
\end{tabular}

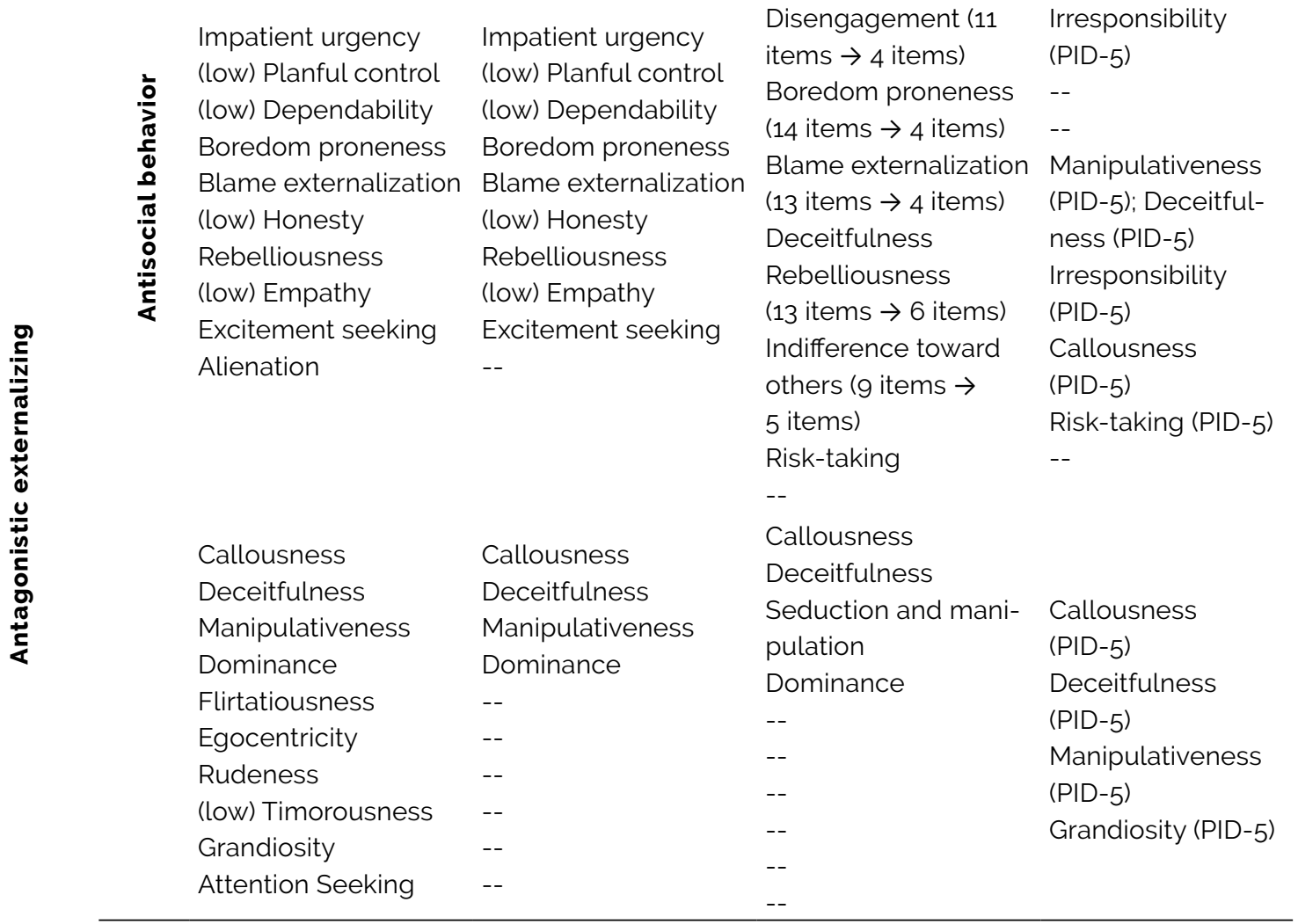

Note: New factors are bolded; in brackets, the number of items developed to the new factor and the final number of items.From the 16 traits (Attention seeking appears in the two spectra), eight were selected as relevant to antisocial behavior. Additionally, 96 new items were developed to represent three traits considered relevant. From them, 35 were chosen to compose the final version of the new factors. The selection was based on clarity, redundancy, and content, as well we verified if the exclusion of any item would decrease the internal consistency of the new factors, which was not observed. 
Step 2 -Psychometric properties verification of the IDCP-ASPD

We investigated the psychometric properties of the item set, starting with the parallel analysis for polychoric variables, determining the maximum number of factors. We obtained up to six factors with significant eigenvalues not randomly established and proceeded the EFA (Marsh, Morin, Parker, \& Kaur, 2014), forcing solutions of two to six factors using the Geomin oblique rotation and the Maximum Likelihood Robust (MLR) as extraction method, considered a robust method suitable for polychoric variables.
Fit indexes improved according to the increase of factors. The best relation fit indexes and interpretability were observed for the 3-factors solution. The fit indexes obtained were $\mathrm{X} 2 / \mathrm{df}=$ 2.65 (acceptable); RMSEA = .09 (marginally acceptable); CFI = .92 (marginally acceptable); $\mathrm{TLI}=0.87$ (marginally acceptable); and SMR $=0.04$ (good), based on (Hooper, Coughlan, \& Mullen, 2008). Table 2 shows factors loadings, an average of the correlations between the measures composing the factor, and internal consistency (Cronbach's $\alpha$ ) for measures and factors. The measures considered as composing each factor are bolded.

Table 2 - Factor loadings of IDCP-2 measures and developed measures to IDCP-ASPD

\begin{tabular}{|c|c|c|c|c|}
\hline & & E. antagonistic & E. disinhibited & E. antagonistic \\
\hline & $\alpha$ & Manipulativeness & $\begin{array}{l}\text { Impulsive } \\
\text { opposition }\end{array}$ & Callousness \\
\hline Risking Taking & .90 & .43 & .71 & .49 \\
\hline Seduction and manipulation & .78 & .87 & .36 & .26 \\
\hline Dominance & .81 & .79 & .31 & .35 \\
\hline Callousness & .71 & .25 & .50 & .77 \\
\hline Impulsivity & .76 & .27 & .69 & .54 \\
\hline Deceitfulness & .80 & .65 & .49 & .57 \\
\hline Irresponsibilitya & .74 & .25 & .85 & .51 \\
\hline Theft ${ }^{\mathrm{a}}$ & .84 & .43 & .54 & .57 \\
\hline Disengagement $^{a}$ & .73 & .22 & 69 & .47 \\
\hline Boderomness ${ }^{a}$ & .80 & .39 & 61 & .36 \\
\hline Blame Externalization ${ }^{a}$ & .81 & .34 & .48 & .33 \\
\hline Rebelliousness $^{\mathrm{a}}$ & .82 & .53 & .70 & .50 \\
\hline Indifference toward others ${ }^{a}$ & .76 & .29 & .52 & .79 \\
\hline Impatient urgencya & .83 & $.40^{*}$ & .35 & $.45^{*}$ \\
\hline$r_{\text {average }}$ & & .46 & .38 & .42 \\
\hline A & .88 & .81 & .85 & .74 \\
\hline
\end{tabular}

Note: adeveloped measures; " The measure was excluded from the higher-order factor because it decreased the reliability and the mean correlation between the variables. E. antagonistic = Externalizing antagonistic. $\mathrm{E}$. disinhibited $=$ Externalizing disinhibited.

New factors and IDCP-2 factors were distributed according to the 3 -factors solution, showing internal consistency higher than 80 for most factors (from .71 to .90 ). The average correlations of measures composing each factor suggest consistency for the three higher-order factors. In the first line of the table, the respective spectrum from HiTOP is presented by each factor. Table 3 shows the correlations between IDCP-ASPD factors and PID-5 factors. 
Table 3 - Correlations between IDCP-2 measures, new measures, and PID-5 facets

\begin{tabular}{|c|c|c|c|c|c|c|c|}
\hline & 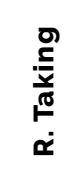 & $\frac{\dot{0}}{\frac{1}{2}}$ & $\begin{array}{l}\frac{\lambda}{n} \\
\frac{+}{0} \\
\frac{0}{0} \\
\frac{c}{0} \\
\frac{0}{0}\end{array}$ & 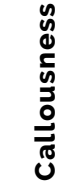 & $\begin{array}{l}\frac{\lambda}{z} \\
\frac{a}{n} \\
\frac{0}{0} \\
\frac{0}{E}\end{array}$ & 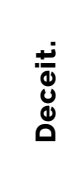 & 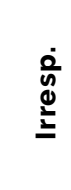 \\
\hline Risk taking & $.70^{* *}$ & $.27^{* *}$ & $.29^{* *}$ & $.36^{* *}$ & $.31^{* *}$ & $.33^{* *}$ & $.36^{* *}$ \\
\hline Seduction and manipulation & $.16^{*}$ & $.71^{* *}$ & $.40^{* *}$ & $.20^{* *}$ & .05 & $.44^{* *}$ & $.24^{* *}$ \\
\hline Dominance & $.17^{*}$ & $.59^{* *}$ & $.48^{* *}$ & $.17^{*}$ & .10 & $.30^{* *}$ & $.15^{*}$ \\
\hline Callousness & $.15^{*}$ & $.19^{* *}$ & $.20^{* *}$ & $.54^{* *}$ & $.24^{* *}$ & $.35^{* *}$ & $.26^{* *}$ \\
\hline Impulsivity & $.44^{* *}$ & .09 & $.14^{*}$ & $.33^{* *}$ & $60^{* *}$ & $.22^{* *}$ & $.37^{* *}$ \\
\hline Deceitfulness & $.19^{* *}$ & $.61^{* *}$ & $39^{* *}$ & $.45^{* *}$ & .06 & $.64^{* *}$ & $.26^{* *}$ \\
\hline Irresponsibilitya & $.37^{* *}$ & $.15^{*}$ & .08 & $.36^{* *}$ & $.36^{* *}$ & $.33^{* *}$ & $.66^{* *}$ \\
\hline Thefta & .12 & $.28^{* *}$ & $.18^{* *}$ & $.35^{* *}$ & .03 & $.34^{* *}$ & $.29^{* *}$ \\
\hline Disengagementa & $.16^{*}$ & $.18^{* *}$ & .13 & $.23^{* *}$ & $.23^{* *}$ & $30^{* *}$ & $.61^{* *}$ \\
\hline Boredomnessa & $.27^{* *}$ & $.32^{* *}$ & $.29^{* *}$ & $.32^{* *}$ & $.28^{* *}$ & $.33^{* *}$ & $.37^{* *}$ \\
\hline Blame Externalizationa & .10 & $.24^{* *}$ & $.25^{* *}$ & $.25^{* \star}$ & $.19^{* *}$ & $.22^{* *}$ & $.27^{* *}$ \\
\hline Rebelliousnessa & $.34^{* *}$ & $.33^{* *}$ & $.36^{* *}$ & $38^{* *}$ & $.28^{* *}$ & $.37^{* *}$ & $.43^{* *}$ \\
\hline Indifference toward othersa & $.15^{*}$ & $.20^{* *}$ & $.23^{* *}$ & $.54^{* *}$ & $.20^{* *}$ & $.34^{* *}$ & $.22^{* *}$ \\
\hline Impatient urgencya & .01 & $.31^{* \star}$ & $.37^{* *}$ & $.42^{* *}$ & $.34^{* *}$ & $.33^{* *}$ & $.15^{*}$ \\
\hline Manipulativenessb & $.20^{* *}$ & $.75^{* *}$ & $.49^{* *}$ & $30^{* *}$ & .08 & $.52^{* *}$ & $.25^{* *}$ \\
\hline Impulsive oppositionb & $.44^{* *}$ & $.33^{* *}$ & $31^{* *}$ & $.45^{* *}$ & $.41^{* *}$ & $.42^{* *}$ & $.58^{* *}$ \\
\hline Callousnessb & $.17^{*}$ & $.26^{* *}$ & $.25^{* *}$ & $.59^{* *}$ & $.21^{* *}$ & $.41^{* *}$ & $.31^{* *}$ \\
\hline IDCP-ASPD total score & $.30^{* *}$ & $.54^{* *}$ & $.52^{* *}$ & $.53^{* *}$ & $31^{* *}$ & $.55^{* *}$ & $.46^{* *}$ \\
\hline
\end{tabular}

Note: $\mathrm{a}$ = developed measures; $\mathrm{b}$ = higher order factors; Gray cells highlight correlations between IDCP-2 factors and the respective external measure according to Table $1 .{ }^{* *}$ Correlation is significant at the 0.01 level; ${ }^{*}$ Correlation is significant at the 0.05 level. Statistical power was $\geq .80$. R. taking = Risk-taking; Manip. = Manipulativeness; Deceit. = Deceitfulness; Irresp. = Irresponsibility.

In general, we observed that the higher correlations were with the expected external measure, although there were some exceptions (i.e., Dominance*Manipulativeness; Theft ${ }^{*}$ Callousness; and Impatient urgency ${ }^{*}$ Callousness). Even in cases where the higher correlation was not with the expected external measure, the correlation with the expected external measure was still highest. Two cases presented no a priori expectations, Boredomness and Blame externalization, both showing higher correlations with Irresponsibility, although Blame externalization tended to have only poor correlations. Total score correlations showed that IDCP-ASPD is correlated with all external measures, and the correlations with the higher-order factors were according to what was observed in Table 2. Table 4 presents results on non-clinical and psychiatric groups comparison. 
Table 4 - Comparison between non-clinical $(n=66)$ and psychiatric $(n=29)$ groups in factors from IDCP-ASPD

\begin{tabular}{|c|c|c|c|c|c|c|c|c|}
\hline \multirow{2}{*}{ Factors } & \multirow{2}{*}{ Groups } & \multirow{2}{*}{ Mean } & \multirow{2}{*}{ SD } & \multicolumn{2}{|c|}{ BCa $95 \% \mathrm{Cl}$} & \multirow[t]{2}{*}{$\mathbf{T}$} & \multirow[t]{2}{*}{ Df } & \multirow[t]{2}{*}{$p(d)$} \\
\hline & & & & Lower & Upper & & & \\
\hline \multirow{2}{*}{ Risk-taking } & - & 1.30 & .45 & 1.20 & 1.42 & \multirow{2}{*}{-1.30} & \multirow{2}{*}{93} & \multirow{2}{*}{$.19(0.30)$} \\
\hline & + & 1.45 & .62 & 1.25 & 1.68 & & & \\
\hline \multirow{2}{*}{$\begin{array}{l}\text { Seduction and } \\
\text { manipulation }\end{array}$} & - & 1.85 & .72 & 1.68 & 2.02 & \multirow[b]{2}{*}{-3.25} & \multirow[b]{2}{*}{93} & \multirow[b]{2}{*}{$.005(0.72)$} \\
\hline & + & 2.42 & .90 & 2.08 & 2.76 & & & \\
\hline \multirow{2}{*}{ Dominance } & - & 2.13 & .66 & 1.98 & 2.29 & \multirow{2}{*}{-2.43} & \multirow{2}{*}{93} & \multirow{2}{*}{$.018(0.54)$} \\
\hline & + & 2.48 & .57 & 2.23 & 2.68 & & & \\
\hline \multirow{2}{*}{ Callousness } & - & 1.42 & .49 & 1.31 & 1.54 & \multirow{2}{*}{-.43} & \multirow{2}{*}{93} & \multirow{2}{*}{$.66(0.10)$} \\
\hline & + & 1.47 & .55 & 1.27 & 1.68 & & & \\
\hline \multirow{2}{*}{ Impulsivity } & - & 1.43 & .43 & 1.33 & 1.54 & \multirow{2}{*}{-2.02} & ? & (050 (015) \\
\hline & + & 1.64 & .51 & 1.45 & 1.83 & & 93 & .05910 .45 \\
\hline Dereitfulness & - & 1.52 & .51 & 1.39 & 1.64 & -110 & & \\
\hline vecertinutess & + & 1.68 & .49 & 1.50 & 1.88 & -1.49 & 93 & .1310 .331 \\
\hline Irresponsibility & - & 1.18 & .27 & 1.11 & 1.25 & -255 & & (0) \\
\hline 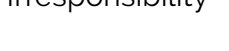 & + & 1.39 & .54 & 1.20 & 1.60 & -2.55 & 93 & .55 \\
\hline Theft & - & 1.03 & .10 & 1.01 & 1.06 & & & \\
\hline मान & + & 1.12 & .32 & 1.02 & 1.26 & -2.14 & 93 & $.13(0.40)$ \\
\hline Disengage- & - & 1.29 & .37 & 1.20 & 1.38 & -175 & & \\
\hline ment & + & 1.47 & .60 & 1.25 & 1.71 & $-1 . / 5$ & 93 & 1. \\
\hline Reredemnecs & - & 1.76 & .73 & 1.59 & 1.93 & 20 & 20 & ( \\
\hline 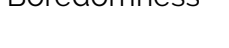 & + & 2.32 & .78 & 2.05 & 2.62 & 3.30 & 93 & (3) \\
\hline Blame Externa- & - & 1.31 & .42 & 1.22 & 1.41 & -212 & 92 & Oด(076) \\
\hline lization & + & 1.69 & .66 & 1.47 & 1.95 & $3.4<$ & 93 & (2) \\
\hline Robollisucnoca & - & 1.35 & .36 & 1.26 & 1.44 & 246 & ? & $006(076)$ \\
\hline 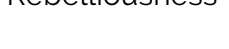 & + & 1.69 & .59 & 1.49 & 1.91 & 3.40 & 930 & ו \\
\hline Indifference & - & 1.28 & .38 & 1.19 & 1.38 & 72 & ?ת & $11(0,16)$ \\
\hline toward others & + & 1.34 & .33 & 1.22 & 1.47 & .18 & 93 & .4410 .101 \\
\hline Impatient & - & 1.85 & .66 & 1.68 & 2.01 & 212 & בת & ( \\
\hline urgency & + & 2.39 & .80 & 2.10 & 2.68 & $-3.4 c$ & 93 & .004 ( $10 . / 01$ \\
\hline Manipulative- & - & 1.83 & .53 & 1.71 & 1.96 & 208 & P & $01(067)$ \\
\hline ness & + & 2.20 & .57 & 1.01 & 1.98 & 2.90 & (93) & (1) \\
\hline Impulsive & - & 1.33 & .25 & 1.27 & 1.40 & -420 & 93 & (0, (0) (0) \\
\hline opposition & + & 1.60 & .33 & 1.50 & 1.73 & & كנ & \\
\hline Callousness & - & 1.25 & .26 & 1.19 & 1.31 & -115 & 3 & $025(023)$ \\
\hline & + & 1.31 & .28 & 1.22 & 1.42 & -1.15 & 93 & 0.2510 .231 \\
\hline IDCP-ASPD & - & 2.20 & .41 & 2.10 & 2.29 & & & \\
\hline total score & + & 2.64 & .44 & 2.48 & 2.79 & & 93 & $.001(1.04)$ \\
\hline
\end{tabular}

Note: (-) non-clinical group; (+) psychiatric group. Statistical power was $\geq .80$ for $d \geq .55$. Higher means for the psychiatric group were observed for all factors, although not all were significant or showed expressive effect size. Higher differences were observed for Blame externalization, Rebelliousness, Impatient urgency, and Boredomness. Higher-order factors and IDCP-ASPD total score effect sizes ranged from 0.23 to 1.04. 


\section{Discussion}

ASPD traits are present in the general population, and their extreme manifestation can cause impairments in various areas of everyday life (Robins et al., 1991; Wallace et al., 2009). Although ASPD prevalence is higher in men (Derefinko \& Widiger, 2016; Glenn et al., 2013)(Compton, Conwat, Stinson, Colliver \& Grant, 2005) in comparison to women, the overall index can reach 3.3\% when not controlling sex (APA, 2013). In the HiTOP perspective (Kotov et al., 2017), ASPD traits are related to disinhibited externalizing and antagonistic externalizing spectra. This study aimed to develop the IDCP-ASPD, i.e., a specific version of the IDCP-2 focused on ASPD traits based on HiTOP. Findings presented in this study indicate the usefulness of the scale for group discrimination according to ASPD traits level. However, it should be considered initial pieces of evidence for IDCP-ASPD.

Based on HiTOP, we selected factors, i.e., traits encompassed by the disinhibited externalizing and antagonistic externalizing spectra (see Kotov et al., 2017). As presented in Table 1, we did not include the alienation trait in our study. Alienation refers to a strong feeling that others are using, manipulating, or mistreating oneself (Krueger et al., 2007). This conceptualization did not reflect ASPD traits and was not supported by previous studies as a component of this disorder (Coid, 2003; Wallace et al., 2009).

We did not anticipate a specific a priori structure in the factorial exploration, as there's no expected grouping at the level of the trait in the HiTOP (Kotov et al., 2017). The factors obtained using the EFA procedure were coherent and representative of the ASPD (Conway et al., 2018; Gomez \& Corr, 2014; Kotov et al., 2017; Wright \& Simms, 2015), grouping characteristics from three mains psychological dysfunctional areas: Manipulativeness, Impulsive opposition, and Callousness. The first englobes traits related to the need to seducing and dominate and use other people based on oneself interest; the impulsive opposition reflects the tendency to blame others for any unsuccessful situation, imprudent style, and need to seek risk situations; the Callousness factor is related to low concern for others (APA, 2013; Hopwood et al., 2012; Krueger et al., 2011).

We highlight the findings on the impatient urgency factor. This factor presented cross-loadings, which is not desirable for EFA, reducing the discrimination between factors. The impatient urgency factor represents the urgency of immediate satisfaction of one's needs/desires (Wallace et al., 2009) and was moderately correlated with PID-5's impulsivity. However, this factor also showed a good discrimination capacity between psychiatric and non-clinical. Therefore, guided by the external validity more than by the internal structure indicators (American Psychological Association, American Educational Research Association, \& National Council on Measurement in Education [(AERA, APA, \& NCME, 2014)]), we decided to maintain this factor in the IDCP-ASPD, as the initial findings suggested the improvement to the assessment of ASPD traits when using the impatient urgency factor, as expected (Conway et al., 2018; Kotov et al., 2017).

The reliability of the factors composing IDCP-ASPD was tested according to internal consistency (Cronbach's $\alpha$ ). Findings for specific IDCP-ASPD factors, higher-order factors, and total score were suitable for the test's clinical use (APA, AERA, \& NCME, 2014). However, about $40 \%$ of the factors showed alpha between .70 and .80 , which must be accounted for by professionals when using it (Taber, 2017).

Correlations presently observed were coherent with the externalizing spectra, showing that these traits can be grouped in some level, as proposed by the HiTOP model (Conway et al., 2018; Kotov et al., 2017) and other studies (Forbes et al., 2017; Forbush \& Watson, 2013; Krueger, Markon, Patrick, Benning, \& Kramer, 2007). Correlations between IDCP-ASPD total score and external measures were moderate to large (Cohen, 1992). Correlations between IDCP-ASPD specific factors and external measures, in general, were according to the expected (see Table 1), confirm previous literature (Crego \& Widiger, 2016; Hopwood et al., 2012; Kotov et al., 2017; Krueger et al., 2012). Exceptions to it were three: Dominance with 
Manipulativeness, Theft with Callousness, and Impatient urgency with Callousness, as discussed in the following paragraphs.

People high in Dominance (i.e., need to dominate others) use manipulation as one of the principal means to have people in control (Crego \& Widiger, 2016). Indeed, the Dominance factor from IDCP-2 (Carvalho \& Primi, 2018; Carvalho, Sette, et al., 2016) is composed of items related to manipulation (e.g., "I know how to use words to get what I want from people."), which may explain the observed correlations. Something similar was observed for the association between Theft and Callousness (slightly larger than the expected with Deceitfulness), which may be explained by the intimate relationship between the callousness trait and deceptive and lying behaviors (Garcia et al., 2018; Kahn, Byrd, \& Pardini, 2013).

No a priori association was presented for two factors: Boredomness and Blame externalization. External measures evaluating both traits were not administered because we could not find scales adapted to Brazil measuring it. Boredomness is related to the difficulty of getting entertained or quickly bored by activities (Krueger et al., 2007). People high in boredomness tend to seek new activities to feel entertained. By doing so, they may engage impulsively in situations where they are less concerned about their own or other safety (i.e., risk-taking), or even lower commitment with rules or obligations (i.e., irresponsibility) (Krueger et al., 2007; Lynam \& Vachon, 2012). These associations should be more explored in futures studies and with a specific psychiatric sample. Regarding Blame externalization, or the tendency to blame others for their failures (Krueger et al., 2007). We also found associations between Blame Externalization with Boredomness. This trait regards low concern about other people and rules, which may lead these people to behave recklessly, without weighing the consequences of their actions (Krueger et al., 2007; Lynam \& Vachon, 2012), explaining the associations observed.

As presented in Table 4, the IDCP-ASPD scale was able to discriminate between psychiatric and non-clinical samples. Impulsive opposition factor demonstrated higher discriminative power among groups. As this trait involves core traits of the ASPD (Kotov et al., 2017), including the tendency to show a reckless style and the need for risk situations, these findings are coherent. Although the impulsive opposition has presented the best prediction capacity, the other factors also showed good prediction, as expected according to previous literature on ASPD traits (APA, 2013; Delisi et al., 2013; Jones, Miller, \& Lynam, 2011). Moreover, these findings suggest that both, disinhibited and antagonistic externalizing spectra, are necessary to a full assessment of the ASPD (Kotov et al., 2017; Krueger \& Markon, 2014).

This is a preliminary study that aimed to develop and verify psychometric properties of a version of the IDCP-2 focused on ASPD traits (i.e., IDCP-ASPD scale), as proposed in HiTOP. As predicted, some factors from IDCP-ASPD were associated with other scales for ASPD traits evaluation, presenting internal consistency and criteria validity. Moreover, the scale was able to discriminate psychiatric and non-clinical groups, which indicates good external validity (AERA et al., 2014), and adequacy in identify pathological behavior.

\section{Limitations and Future Directions}

We highlight the main limitations of this study. Our psychiatric group was small and heterogeneous, which may have impacted the results. Specifically, as noted in Table 4, not all comparisons presented enough statistical power. We understand that a higher number of subjects and a more homogeneity sample with known diagnostic may bring further information on the IDCP-ASPD scale. Besides administering it in larger diagnosed samples and presenting accuracy indicators (e.g., sensitivity and specificity), we strongly recommend external validity studies, including measures related to the traits evaluated by the IDCP-ASPD.

\section{Compliance with Ethical Standards}

The authors declare no potential conflicts of interest. This research involved human partici- 
pants and was previously approved by the Brazilian Ethical Committee. All participants signed an informed consent form before starting the data collection.

\section{References}

AERA, A. E. R. A., APA, A. P. A., \& NCME, N. C. on M. in E. (2014). Standards for educational and psychological testing. American Educational Research Association.

Anderson, J. L., Sellbom, M., Ayearst, L. E., Quilty, L. C., Chmielewski, M., \& Bagby, R. M. (2015). Associations between DSM-5 Section III person- ality traits and the Minnesota Multiphasic Personality Inventory 2- Restructured Form (MMPI-2-RF) scales in a psychiatric patient sample. Psychological Assessment, 27, 801-815. https://doi.org/10.1037/pas0000096

APA, A. P. A. (2013). Diagnostic and Statistical Manual of Mental Disorders, Fifth Edition (DSM-5). American Psychiatric Publishing.

Brito, S. A., \& Hodgins, S. (2009). Antisocial personality disorder. Personality, personality disorder and violence. $42,133-153$

Carvalho, L. F. (2018). Review study of the Impulsiveness Dimension of the Dimensional Clinical Personality Inventory. Universitas Psychologica, 17, 1-11. https://doi. org/10.11144/Javeriana.upsy17-1.rsid

Carvalho, L. F., \& Martins, D. M. (2017). Revisão da dimensão Desconfiança do Inventário Dimensional Clínico da Personalidade. PSICO, 48, 152-162. https://doi. org/10.15448/1980-8623.2017.2.24823

Carvalho, L. F., Pianowski, G., \& Miguel, F. K. (2015). Revision of the aggressiveness dimension of Dimensional Clinical Personality Inventory. Psicologia: Teoria e Prática, 17(3), 146-163. https://doi.org/10.15348/1980-6906/ psicologia.v17n3p146-163

Carvalho, L. F., Pianowski, G., Silveira, F. J., Bacciotti, J. T., \& Vieira, P. G. (2016). Eccentricity dimension of the Dimensional Clinical Personality Inventory: Review and psychometric properties. Estudos de Psicologia, 21(4), 359-368. https://doi.org/10.5935/1678-4669.20160035

Carvalho, L. F., \& Primi, R. (2016). Prototype matching of personality disorders with the Dimensional Clinical Personality Inventory. Psicologia: Teoria e Pesquisa, 32(2), 1-9. https://doi.org/10.1590/0102-3772e322214

Carvalho, L. F., \& Primi, R. (2018). Inventário Dimensional Clínico da Personalidade 2 (IDCP-2) e Inventário Dimensional Clinico da Personalidade - versão triagem (IDCP-triagem). Pearson.

Carvalho, L. F., Sette, C. P., \& Ferrari, B. L. (2016). Revision of the gransiosity dimension of the Dimensional Clinical Personality Inventory and verification of its psychometric properties. Trends in Psychiatry and Psychotherapy, 1, 1-9. https://doi.org/10.1590/2237-6089-2015-0040

Cohen, J. (1992). A power primer. Psychological Bulletin, 112(1), 155-159. https://doi.org/10.1037/00332909.112.1.155
Coid, J. (2003). Epidemiology, public health and the problem of personality disorder. The British Journal of Psychiatry, 182(S44), 3-10. https://doi.org/10.1192/ bjp.182.44.s3

Coid, J., \& Ullrich, S. (2010). Antisocial personality disorder is on a continuum with psychopathy. Comprehensive Psychiatry, 51(4), 426-433. https://doi.org/10.1016/j. comppsych.2009.09.006

Compton, W. M., Conway, K. P., Stinson, F. S., Colliver, J. D., \& Grant, B. F. (2005). Prevalence, Correlates, and Comorbidity of DSM-IV Antisocial Personality Syndromes and Alcohol and Specific Drug Use Disorders in the United States: Results From the National Epidemiologic Survey on Alcohol and Related Conditions. The Journal of Clinical Psychiatry, 66(6), 677-685. https:// doi.org/10.4088/JCP.v66no6o2

Conselho Nacional de Saúde. Resolução no 510/2016. (2016).

Conway, C., Forbes, M. K., Forbush, K. T., Fried, E. I., Hallquist, M. N., Kotov, R., ... Eaton, N. R. (2018). A Hierarchical Taxonomy of Psychopathology Can Transform Mental Health Research. https://doi.org/10.17605/ OSF.IO/WSYGP

Crego, C., \& Widiger, T. A. (2016). Convergente and discrimimant validity of alternative measures of maladaptative personality traits. Psychological Assessment. https://doi.org/10.1037/pas0000282

Delisi, M., Angton, A., Vaughn, M. G., Trulson, C. R., Caudill, J. W., \& Beaver, K. M. (2014). Not my fault: Blame externalization is the psychopathic feature most associated with pathological delinquency among confined delinquents. International Journal of Offender Therapy and Comparative Criminology, 58(12), 1415-1430. https:// doi.org/10.1177/0306624X13496543

Derefinko, K. J., \& Widiger, T. A. (2016). Antisocial personality disorder. In The medical basis of psychiatry (p. 229-245). Springer. https://doi.org/10.1007/978-14939-2528-5_13

Fazel, S., \& Danesh, J. (2002). Serious mental disorder in 23000 prisoners: a systematic review of 62 surveys. Lancet, 359(9306), 545-550. https://doi.org/10.1016/ s0140-6736(02)07740-1

Forbes, M. K., Kotov, R., Ruggero, C. J., Watson, D., Zimmerman, M., \& Krueger, R. F. (2017). Delineating the joint hierarchical structure of clinical and personality disorders in an outpatient psychiatric sample. Comprehensive Psychiatry, 79, 19-30. https://doi.org/10.1016/j.comppsych.2017.04.006

Forbush, K. T., \& Watson, D. (2013). The structure of common and uncommon mental disorders. Psychological Medicine, 1, 97-108. https://doi.org/10.1017/ So033291712001092

Garcia, C. H., Valle, A., Daniel, L., Grimaldo, N., Grimaldo, B., \& Calderón, C. (2018). Psychopathy as a Predictor Variable of The Disposition to Steal. Revista Iberoamericana de Psicologia y Salud, 9(2), 137-148. https://doi. org/10.23923/j.rips.2018.02.019 
Glenn, A. L., Johnson, A. K., \& Raine, A. (2013). Antisocial personality disorder: a current review. Current Psychiatry Reports, 15(12). https://doi.org/10.1007/ s11920-013-0427-7

Gomez, R., \& Corr, P. J. (2014). ADHD and personality: A meta-analytic review. Clinical Psychology Review, 34(5), 376-388. https://doi.org/10.1016/j.cpr.2014.05.002

Hengartner, M., P., \& Lehmann, S. N. (2017). Why Psychiatric Research Must Abandon Traditional Diagnostic Classification and Adopt a Fully Dimensional Scope: Two Solutions to a Persistent Problem. Frontiers in Psychiatry, 8, 101. https://doi.org/10.3389/fpsyt.2017.00101

Hooper, D., Coughlan, J., \& Mullen, M. R. (2008). Structural Equation Modeling: Guidelines for Determining Model Fit. Electronic Journal on Business Research Methods, 6(1). https://goo.gl/L1Sm2V.

Hopwood, C. J., Thomas, K. M., Markon, K., Wright, A. G. C., \& Krueger, R. F. (2012). DSM-5 personality traits and DSM-IV personality disorders. Journal of Abnormal Psychology, 121(2), 424-432. https://doi.org/10.1037/ a0026656

Jones, S. E., Miller, J. D., \& Lynam, D. R. (2011). Personality, antisocial behavior, and aggression: A meta-analytic review. Journal of Criminal Justice, 39(4), 329-337. doi:10.1016/j.jcrimjus.2011.03.004

Kahn, R. E., Byrd, A. L., \& Pardini, D. A. (2013). Callous-unemotional traits robustly predict future criminal offending in young men. Law and Human Behavior, 37(2), 87-97. https://doi.org/10.1037/b0000003

Kotov, R., Krueger, R. F., Watson, D., Achenbach, T. M., Althoff, R. R., Bagby, R. M., ... Wright, A. G. C. (2017). The Hierarchical Taxonomy of Psychopathology (HiTOP): A Dimensional Alternative to Traditional Nosologies. Journal of Abnormal Psychology, 126(4), 454-477. https:// doi.org/10.1037/abno000258

Krueger, R. F., Derringer, J., Markon, K. E., Watson, D., \& Skodol, A. E. (2012). Initial construction of a maladaptive personality trait model and inventory for DSM-5. Psychological Medicine, 42(9), 1879-1890. https://doi. org/10.1017/So03329171100267

Krueger, R. F., Eaton, N. R., Clark, L. A., Watson, D., Markon, K. E., Derringer, J., ... Livesley, W. J. (2011). Deriving an empirical structure of personality pathology for DSM-5. Journal of Personality Disorders, 25(2), 170-191. https://doi.org/10.1521/pedi.2011.25.2.170

Krueger, R. F., \& Markon, K. (2014). The role of the DSM-5 personality trait model in moving toward a quantitative and empirically based approach to classifying personality and psychopathology. Annual Review of Clinical Psychology, 10, 477-501. https://doi.org/10.1146/annurev-clinpsy-032813-153732

Krueger, R. F., Markon, K., Patrick, C. J., Benning, S. D., \& Kramer, M. D. (2007). Linking antisocial behavior, substance use, and personality: An integrative quantitative model of the adult externalizing spectrum. Journal of Abnormal Psychology, 4(116), 645-666. https://doi. org/10.1037/0021-843X.116.4.645
Lynam, D. R., \& Vachon, D. D. (2012). Antisocial personality disorder in DSM-5: Missteps and missed opportunities. Personality Disorders: Theory, Research, and Treatment, 3(4), 483-495. https://doi.org/10.1037/per0000006

Marcus, D. K., Lilienfeld, S. O., Edens, J. F., \& Poythress, N. G. (2006). Is antisocial personality disorder continuous or categorical? A taxometric analysis. Psychological Medicine, 36(11), 1571-1581. https://doi.org/10.1017/ So033291706008245

Marsh, H. W., Morin, A. J., Parker, P. D., \& Kaur, G. (2014). Exploratory structural equation modeling: an integration of the best features of exploratory and confirmatory factor analysis. Annual Review of Clinical Psychology, 10, 85-110. https://doi.org/10.1146/annurev-clinpsy-032813-153700

Miller, J. D., Lynam, D., \& Leukefeld, C. (2003). Examining antisocial behavior through the lens of the five factor model of personality. Aggressive Behavior, 29(6), 497514. https://doi.org/10.1002/ab.10064

Pianowski, G., Carvalho, L. de F., \& Miguel, F. K. (2019). Investigating the Spectra constellations of the Hierarchical Taxonomy of Psychopathology (HiTOP) model for personality disorders based on empirical data from a community sample. Brazilian Journal of Psychiatry, 41(2), 148-152. https://doi.org/10.1590/1516-4446-2018-0015

Rautiainen, M. R., Paunio, T., Repo-Tiihonen, E., Virkkunen, M., Ollila, H. M., Sulkava, S., ... Tiihonen, J. (2016). Genome-wide association study of antisocial personality disorder. Translational Psychiatry, 6. https://doi. org/10.1038/tp.2016.155

Robins, L. N., Tipp, J., \& Pryzbeck, T. (1991). Antisocial personality. In L. N. Robins \& D. A. Regier, Psychiatric disorders in America: The epidemiologic catchment area study (pp. 258-290). Free Press.

Santana, G. L., Coelho, B. M., Wang, Y.-P., Chiavegatto Filho, A. D. P., Viana, M. C., \& Andrade, L. H. (2018). The epidemiology of personality disorders in the Sao Paulo Megacity general population. PLOS ONE, 13(4). https:// doi.org/10.1371/journal.pone.0195581

Taber, K. S. (2017). The use of cronbach's alpha when developing and reporting research instruments in science education. Research in Science Education, 48, 1273-1296. https://doi.org/10.1007/s11165-016-9602-2

Wallace, J. F., Malterer, M. B., \& Newman, J. P. (2009). Mapping Gray's BIS and BAS constructs onto factor 1 and factor 2 of Hare's psychopathy checklist-revised. Personality and Individual Differences, 47(8), 812-816. https://doi.org/10.1016/j.paid.2009.06.019

Walters, G. D. (2008). Self-Report Measures of Psychopathy, Antisocial Personality, and Criminal Lifestyle: Testing and Validating a Two-Dimensional Model. Criminal Justice and Behavior, 35(12), 1459-1483. https:// doi.org/10.1177/0093854808320922

Whitbourne, S. K., \& Halgin, R. P. (2015). Transtornos da Personalidade. In S. K. Whitbourne \& R. P. Halgin, Psicopatologia: perspectiva clínica dos transtornos psicológicos (7. Ed., pp. 349-375). Artmed. 
Widiger, T. A. (2011). A shaky future for personality disorders. Personality Disorders: Theory, Research, and Treatment, 2(1), 54-67. https://doi.org/10.1037/a0021855

Wright, A. G., Krueger, R. F., Hobbs, M. J., Markon, K. E., Eaton, N. R., \& Slade, T. (2013). The structure of psychopathology: toward an expanded quantitative empirical model. Journal of Abnormal Psychology, 122(1), 281. https://doi.org/10.1037/a0030133

Wright, A. G., \& Simms, L. J. (2015). A metastructural model of mental disorders and pathological personality traits. Psychological medicine, 45(11), 2309-2319. https:// doi.org/10.1017/S0033291715000252

Yakeley, J., \& Williams, A. (2014). Antisocial personality disorder: new directions. Advances in Psychiatric Treatment, 20(2), 132-143. https://doi.org/10.1192/apt. bp.113.011205

\section{Lucas de Francisco Carvalho}

Doutor pela Universidade São Francisco (USF), em Campinas, SP, Brasil.

\section{Ana Deyvis Santos Araújo Jesuíno}

Doutora pela Universidade São Francisco (USF), em Campinas, SP, Brasil.

\section{Samanta Romanin Zuchetto}

Mestre em Psicologia pela Universidade São Francisco (USF), em Campinas, SP, Brasil.

\section{Ana Carolina Zuanazzi}

Doutora em Psicologia com ênfase em avaliação psicológica pela Universidade São Francisco (USF), em Campinas, SP, Brasil, com estágio na University of Toledo-Ohio.

\section{Endereço para correspondência}

\section{Lucas de Francisco Carvalho}

Universidade São Francisco

R. Waldemar César da Silveira, 105

Jardim Cura D'ars, 13045-510

Campinas, SP, Brasil

Os textos deste artigo foram revisados pela Poá Comunicação e submetidos para validação do(s) autor(es) antes da publicação. 